\title{
Lipase-mediated regioselective modifications of macrolactonic sophorolipids
}

\author{
Aliya Sembayeva ${ }^{\mathrm{a}}$, Beniam Berhane ${ }^{\mathrm{b}}$ and Jason A. Carr ${ }^{\mathrm{a}}$ * \\ ${ }^{a}$ Nazarbayev University, Dept. of Chemistry, 53 Kabanbay batyr Ave., Astana, Republic of Kazakhstan, 010000 \\ bUniversity of California Irvine, Dept. of Chemistry, 1102 Natural Sciences 2, Irvine, California, 92697
}

\begin{abstract}
Chemoenzymatic synthesis and modification of well-defined macrolactonic sophorolipid (SLML) analogues via a series of successive regioselective de-esterification/transesterification reactions is investigated. Of the lipases screened, Candida antartica lipase- B (Novozyme-435) successfully deacylated the C-6' acetoxy group of natural and peracylated SLMLs. Subsequent transesterification with acylating agents (esters of fatty acids) was successful only with the C-6' deacetylated natural SLML providing an avenue to well-defined analogues of varying amphilicity. The macrolactonic motif was essential for enzymatic recognition of the sophorose rings of these complex glycolipids. In the absence of the lactonic motif, the peracylated sophorose rings are not deacylated, rather the carboxyl end of the non-lactonic forms that was preferentially transesterified. All macrolactonic derivatives were characterized by $\mathrm{IR},{ }^{1} \mathrm{H},{ }^{13} \mathrm{C}$, ${ }^{1} \mathrm{H}-{ }^{1} \mathrm{H}$ and ${ }^{1} \mathrm{H}-{ }^{13} \mathrm{C}$ NMR spectroscopy, as well as HRMS where applicable.
\end{abstract}

Keywords:

sophorolipids; glycolipids; lipases; NMR Spectroscopy; lactone; fatty acid esters; biosurfactant

* Corresponding author. Tel.: +7-775-334-7275; e-mail: jacarr@nu.edu.kz; avogadro1998@gmail.com (Jason A. Carr) 


\section{Introduction}

Surface-active biosurfactant agents have attracted much interests due to their unique structures, biodegradability, biochemical and pharmacological properties such antimicrobial, ${ }^{1}$ anticancer, ${ }^{2,3}$ antivirus ${ }^{4}$ and anti-sepsis ${ }^{5}$ actions. Of these, the sophorolipids (SLs) (Figure 1) have attracted broad attention and have been utilized for various applications. Sophorolipids are complex glycolipids comprised of the disaccharide sophorose (2-O- $\beta$-D-glucopyranosyl- $\beta$-Dglucopyranose) linked to a hydroxy fatty acyl group by a glycosidic bond between the 1'anomeric position and the $\omega$ or $\omega-1$ carbon of a fatty acid. They are produced by yeast strains such as Candida bombicola, ${ }^{6}$ Candida apicola ${ }^{7}$ Candida bogoriensis, ${ }^{8}$ Candida batistae ${ }^{9}$ and Wickerhamilella domercqiae ${ }^{10}$ and are usually harvested as a mixture of glycolipids with varying degrees of acetylation on the sophorose moiety. The predominant forms of this mixture are the macrolactonic sophorolipid (SLML, Fig. 1a) and the free carboxylic acid form (SLCA, Fig. 1b) that are acetylated at both the 6'- and 6"- positions, or various combinations thereof, on the sophorose rings.

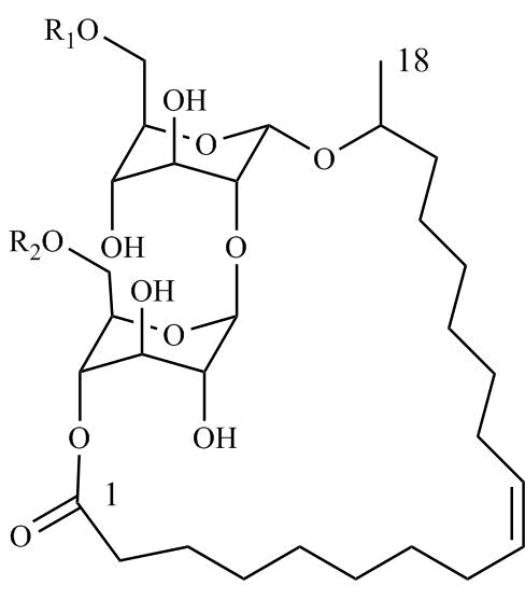

(SLML), $1 \mathbf{a}$

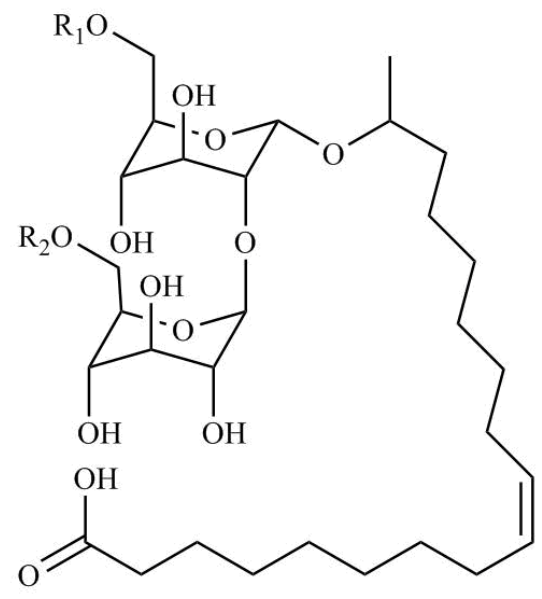

(SLCA), $1 \mathrm{~b}$

Figure 1. The major components of sophorolipids: the macrolactonic form (1a) and the free acid form (1b), $\mathrm{R}_{1}=\mathrm{R}_{2}=\mathrm{CH}_{3} \mathrm{C}(\mathrm{O})$.

Of the two major components, the free carboxylic acid form and its derivatives have been more studied, perhaps because of their stronger interfacial activity and hydrophilicity as compared to the lactonic form. Regardless, modification of either form, to study their interfacial functions and structure-activity relationships, is not a trivial task. There are acid-sensitive 
glycosidic linkages and acid/base-sensitive ester functionalities. Chemical modification of sophorolipids usually requires a series of protection/de-protection steps with limited selectivity, but enzymes provide a powerful tool to selectively modify both forms of sophorolipids and their derivatives. ${ }^{11}$ We have previously shown that lipases, namely Candida antartica lipase (CAL-B), will only modify the carboxyl end of the fatty-acid side chain of the non-lactonic forms of peracylated sophorolipid derivatives. The sophorose glycosyl rings, even when esterified, were unperturbed and unreactive to lipase hydrolysis under reaction conditions similar to those

described within. ${ }^{12}$ Herein, we have shown that when the macrolactonic motif is preserved, the sophorose rings are recognized by the enzyme, Candida antartica lipase (CAL-B), and selective deacylation or acylation is accomplished under mild conditions. Careful selection of the fatty acid esters, the acylating agents, leads to carefully tailored sophorolipids which could lead to analogues of varying levels of amphilicity.

\section{Results and discussion}

\subsection{Regioselective hydrolysis and screening of lipases, solvent and temperature}

In order to determine the best lipase for regio-selective hydrolysis, reactions were modeled using compound 1a incubated with lipases from different sources: Candida antartica B (CALB), Pseudomonas cepecia, AS "Amano", AY "Amano" 30 SD-K, and "Amano" M. The experiments were conducted in dry solvents namely THF, acetonitrile, toluene or cyclohexane as the organic medium carried out in tightly sealed $\mathrm{N}_{2}$-flushed vials containing a solution of $1 \mathbf{a}$ with $n$-butanol in the dry solvents and incubated with the different lipases. The choice of solvents reflected those considered to be mid- to low polar solvents as it is known that more polar ones may denature or inactivate enzymes. ${ }^{13}$ The reactions were repeated with temperature variations from $40^{\circ} \mathrm{C}$ to $70^{\circ} \mathrm{C}$ in order to determine the optimal temperature for highest substrate conversion and were allowed to proceed for up to $72 \mathrm{~h}$. 


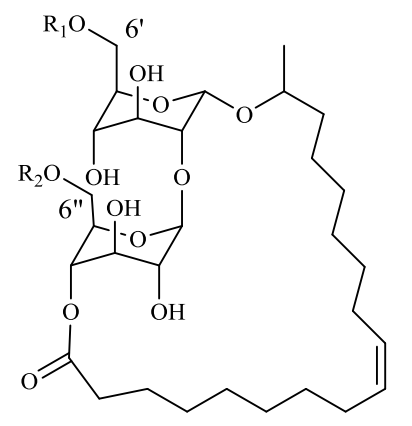

(i)
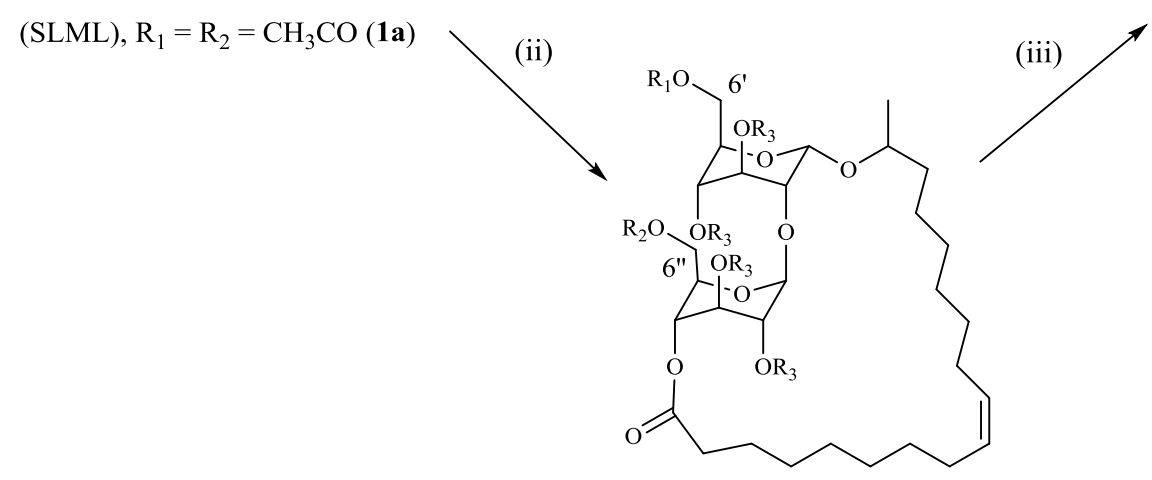

$\mathrm{R}_{2}=\mathrm{CH}_{3} \mathrm{CO}, \mathrm{R}_{3}=\mathrm{H}(\mathbf{4})$

$\mathrm{R}_{2}=\mathrm{R}_{3}=\mathrm{CH}_{3} \mathrm{CO}(\mathbf{5})$

$\mathrm{R}_{2}=\mathrm{CH}_{3} \mathrm{CO}, \mathrm{R}_{3}=\mathrm{CH}_{3} \mathrm{CH}_{2} \mathrm{CO}(\mathbf{6})$

$\mathrm{R}_{1}=\mathrm{R}_{2}=\mathrm{R}_{3}=\mathrm{CH}_{3} \mathrm{CO}$ (2)

$\mathrm{R}_{1}=\mathrm{R}_{2}=\mathrm{CH}_{3} \mathrm{CO}, \mathrm{R}_{3}=\mathrm{CH}_{3} \mathrm{CH}_{2} \mathrm{CO}(3)$

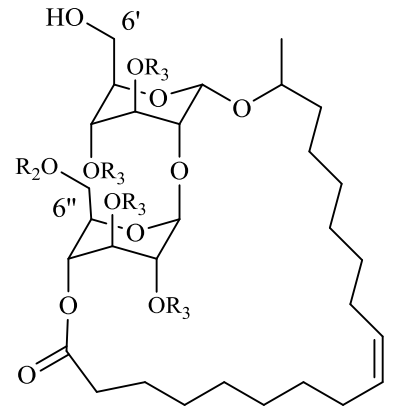

Scheme 1. Synthesis of SLML derivatives and lipase hydrolysis of SLML 1a and its derivatives. (i) Novozym-435, n-butanol, dry $\mathrm{THF}$ at $60^{\circ} \mathrm{C}$ (ii) acetic anhydride or propionic anhydride, pyridine, DMAP, dry THF, 3 h; (iii) Novozym-435, $n$-butanol, dry acetonitrile at $60^{\circ} \mathrm{C}$.

From the modeled reactions only CAL-B and PS-30 seemed to offer any activity, with CAL-B in dry acetonitrile or THF at $60^{\circ} \mathrm{C}$ having noticeably greater activity, giving the highest yield of the 6'-deacetylated substrate, 4 (Scheme 1, m/z $669.35[\mathrm{M}+\mathrm{Na}]^{+}$), in $50 \%$ yield (Table 1). Lower yields were observed when the modeled reaction was done in solvents other than acetonitrile or $\mathrm{THF}$, or at temperatures lower or higher than $60^{\circ} \mathrm{C}$. This can be attributed to a decrease in solubility of the substrate as the solvent's dielectric constant decreases, thereby decreasing the catalytic turnover rate $\left(k_{\mathrm{cat}}\right)$ or denaturation of the enzyme leading to a decrease in activity with temperature variations. No other activity, hydrolytic or otherwise, was observed with the other enzymes that were screened, indicating that the glycolipids were unfit substrates for these biocatalysts. Therefore, CAL-B was chosen as the lipase of choice to carry out further studies on the peracylated derivatives, $2\left(\mathrm{~m} / \mathrm{z}, 879.40[\mathrm{M}+\mathrm{Na}]^{+}\right)$and $\mathbf{3}\left(\mathrm{m} / \mathrm{z}, 935.46[\mathrm{M}+\mathrm{Na}]^{+}\right)$. 
The peracetylated and propionated substrates were formed by reacting 1a with acetic anhydride and propionic anhydride respectively with a catalytic amount of DMAP in dry THF. Subjecting compounds 2 and 3 to CAL-B hydrolysis by incubating the substrates in dry acetonitrile with $n$ butanol for 3 days resulted in highly selective hydrolysis of the 6'-acetoxy group of these peracylated derivatives. The yields obtained were $52 \%$ for the $6^{\prime}$-deacetylated peracetylated derivative $\left(5, \mathrm{~m} / \mathrm{z} 837.39[\mathrm{M}+\mathrm{Na}]^{+}\right)$and $51 \%$ for the $6^{\prime}$-deacetylated propionated derivative $(6$, $\left.\mathrm{m} / z 893.45[\mathrm{M}+\mathrm{Na}]^{+}\right)($Scheme 1, Table 1). It is important to note that longer reaction times of up to 7-10 days had no effect on the yields of the 6'-deacetylated products formed.

\begin{tabular}{|c|c|c|c|c|}
\hline Compound code & Temperature $\left({ }^{\circ} \mathrm{C}\right)$ & Lipase & Solvent & Isolated yield (\%) \\
\hline $1 \mathbf{a}$ & 40 & CAL-B & cyclohexane & 0 \\
\hline $1 \mathbf{a}$ & 50 & CAL-B & cyclohexane & 12 \\
\hline $1 \mathbf{a}$ & 40 & CAL-B & toluene & 30 \\
\hline $1 \mathbf{a}$ & 50 & CAL-B & toluene & 36 \\
\hline $1 \mathbf{a}$ & 60 & CAL-B & toluene & 38 \\
\hline $1 \mathbf{a}$ & 40 & CAL-B & THF & 34 \\
\hline $1 \mathbf{a}$ & 50 & CAL-B & THF & 46 \\
\hline $1 \mathbf{a}$ & 60 & CAL-B & THF & 49 \\
\hline $1 \mathbf{a}$ & 70 & CAL-B & THF & 35 \\
\hline $1 \mathbf{a}$ & 40 & CAL-B & $\mathrm{CH}_{3} \mathrm{CN}$ & 42 \\
\hline $1 \mathbf{a}$ & 50 & CAL-B & $\mathrm{CH}_{3} \mathrm{CN}$ & 47 \\
\hline $1 \mathbf{a}$ & 60 & CAL-B & $\mathrm{CH}_{3} \mathrm{CN}$ & 51 \\
\hline $1 \mathbf{a}$ & 70 & CAL-B & $\mathrm{CH}_{3} \mathrm{CN}$ & 43 \\
\hline $1 \mathbf{a}$ & 50 & PS-30 & $\mathrm{CH}_{3} \mathrm{CN}$ & 5 \\
\hline $1 \mathbf{a}$ & 60 & PS-30 & $\mathrm{CH}_{3} \mathrm{CN}$ & 8 \\
\hline 2 & 60 & CAL-B & $\mathrm{CH}_{3} \mathrm{CN}$ & 52 \\
\hline 3 & 60 & CAL-B & $\mathrm{CH}_{3} \mathrm{CN}$ & 51 \\
\hline
\end{tabular}

Table 1. Solvent and temperature effect on the yield of lipase catalyzed reactions after $72 \mathrm{~h}$. Other lipases excluded as they were unreactive toward the substrates.

That the 6 ' position of the sophorose ring was hydrolyzed selectively is a testament to the remarkable selectivity of biocatalysts, even on the peracylated sophorolipids. Otto et al ${ }^{14}$ has 
shown that deacetylation does occur primarily at the $6^{\prime}$ position when 1a is incubated with Candida rugosa lipase, more likely because the 6" position is more sterically inaccessible to the enzyme's active site given that it is tucked between the fatty acid side chain and the first glucosyl ring of these complex molecules. This was more recently demonstrated by $\mathrm{Ju}^{15}$ who was able to deacetylate compound 1a using MML (Mucor michei lipase) as the most effective biocatalyst as well as other biocatalysts including CAL-B and Gross ${ }^{16}$ who was able achieve the $6^{\prime}$ deacetylation using lipase from Candida rugosa and 6" deacetylation with cutinase from Humicola insolens. All reported modifications of native SLML (1a) to date utilized buffer as the solvent of choice to realize the deacylation of either the 6' or 6" acetates, however, because of the very limited solubility of derivatized SLMLs, careful screening of hydrolytic reactions in nontoxic organic solvents was necessary in keeping with the "green" chemistry involved. More importantly, we have demonstrated that for peracylated macrolactonic derivatives to be recognized by lipases, the lactonic motif is an essential requirement for enzymatic recognition of the glycon head. Without this important structural factor, the enzyme CAL-B only recognizes the aglyconic tail as in modification of the peracylated non-lactonic derivatives. ${ }^{12}$

\subsection{Synthesis of fatty acid esters by lactone ring opening}

In our effort to synthesize sophorolipid analogues of varying levels of amphilicity, fatty-acid esters of various chain lengths were synthesized by the ring-opening of lactones. Fatty-acid esters were chosen as the acylating agents of choice as it is known the CAL-B has high activity for these substrates. ${ }^{17}$ Apart from the ring-opening of cyclopentadecanolide, the ring-opening of $\gamma$ - and $\delta$ - lactones was no trivial task. For cyclopentadecanolide, the ring-opening was accomplished by dissolving the substrate in methanol with a catalytic amount of pTSA and the mixture brought to reflux overnight. Excess solvent was then removed in vacuo, the product taken up and extracted in DCM and water to yield the substrate, methyl 15hydroxypentadecanoate, 7 (Scheme 2). Recognizing that the $\omega$-hydroxymethylene group can diminish reaction between the fatty-acid ester and the $6^{\prime}$-deacetoxy sophorolipids, the substrate 7 was protected with TBDPS by reacting 7 with tert-butyldiphenylsilyl chloride with a catalytic amount of imidazole in DCM which, after purification, yielded methyl 15-(tertbutyldiphenylsilyl)oxy)pentadecanoate (8) as a colorless oil in 55\% yield (Scheme 2). ${ }^{18}$ 


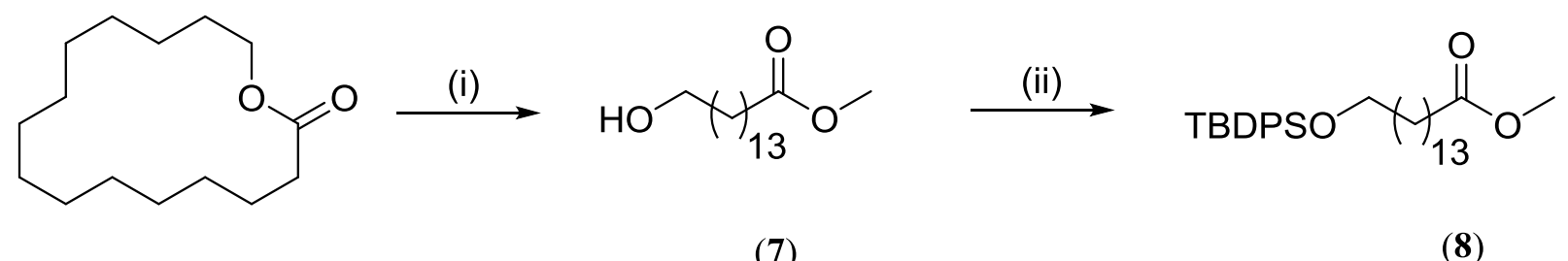

Scheme 2. Synthesis of methyl TBDPS pentadecanoate. (i) pTSA, methanol, reflux; (ii) TBDPSCl, imidazole, DCM.

Unfortunately, the ring-opening of $\gamma$ - and $\delta$ - lactones was not as trivial as that of cyclopentadecanolide. This was mainly because entropy favors the formation of the lactones under those conditions. In order to prepare TBDPS-protected esters from $\gamma$ - and $\delta$ - lactones, the following general reaction conditions were employed. To a solution of a lactone dissolved in ethanol, 1.1 molar equivalents of $\mathrm{NaOH}$ was added and the reaction heated at $80^{\circ}$ for $30 \mathrm{~min}$, then stirred at ambient temperature for 2 hours. After removal of the solvent in vacuo, the salt formed was dissolved in DMF followed by the slow addition of ethyl iodide and the reaction allowed to stir at room temperature for 5 days. After extraction with ethyl acetate and water, the ester was dissolved in DCM followed by addition of TBDPSCl with a catalytic amount of imidazole and the reaction allowed to stir for an additional 2 days. Extraction followed by purification via column chromatography yielded products $(\mathbf{1 0}, \mathbf{1 2})$ as colorless oils with yields ranging from 60\%-70\% (Scheme 3). ${ }^{19}$

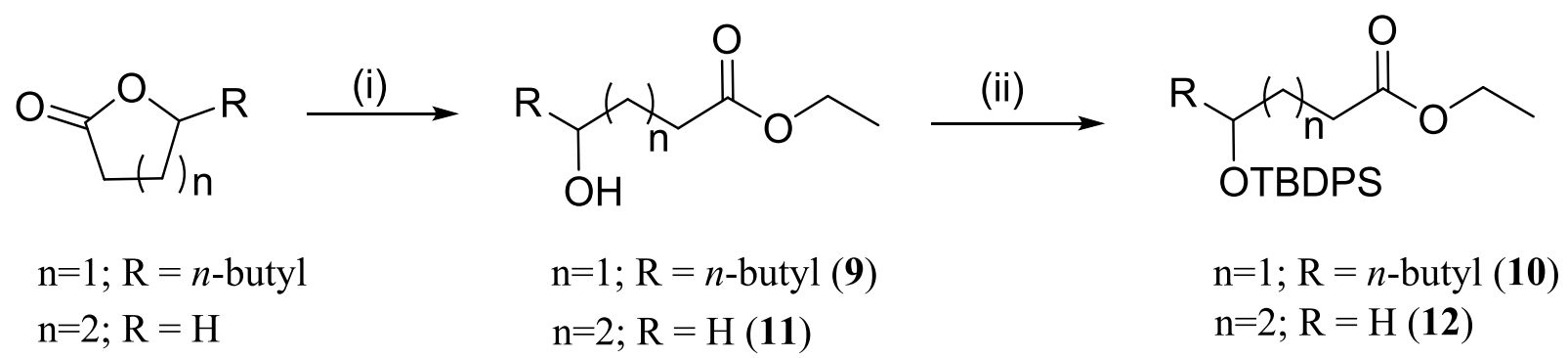

Scheme 3. Synthesis of TBDPS-protected esters from $\gamma$ - and $\delta$ - lactones. (i) $\mathrm{NaOH}$, EtOH then EtI, DMF; (ii) TBDPSCl, imidazole, DCM.

\subsection{Lipase-mediated esterification of 6'-deacetoxy SLMLs}


In order to 'tailor' the amphilicity of the 6'-deacetylated SLMLs, compounds $\mathbf{4 , 5}$ and $\mathbf{6}$ were incubated with the fatty-acid esters derived from the ring-opening of various lactones (Schemes 2, 3). In a typical reaction, Novozym-435 (CAL-B, immobilized preparation from C. antartica) was incubated with the $6^{\prime}$-deacetylated compounds $\mathbf{4 , 5}$ and 6 in $50 \mathrm{~mL}$ round bottom flasks using 1:1 substrate to lipase ratio $(\mathrm{w} / \mathrm{w})$. The transesterification was initially carried out with 4 in dry solvents at $60^{\circ} \mathrm{C}$ in the presence of the fatty-acid esters $(8,10,12)$ and were allowed to incubate for a period of 5 days. It was observed that only compound $\mathbf{8}$ responded to the transesterification conditions employed to yield the lipophilic derivative 13 (Scheme 4, Table 2, $\left.\left[\mathrm{m} / z 1147.67[\mathrm{M}+\mathrm{Na}]^{+}\right]\right)$in relatively low yields. Dry acetonitrile gave the highest yield at $39 \%$ but a higher yield $(61 \%)$ of the product was achieved when the reaction was extended to 30 days. When the center of reactivity of the fatty-acid esters became relatively hindered as seen in $\mathbf{1 0}$ and 12, the reactions failed altogether. It is known that the scissile fatty acid binding site for CAL-B has high activity for short to medium chain length fatty acids and decreasing activity for longchain fatty acids, ${ }^{17}$ so it came as a surprise to observe that no reaction occurred when the shorter chain fatty acids $(\mathbf{1 0}, \mathbf{1 2}$, Table 2$)$ were incubated with CAL-B and $\mathbf{4}$. It is suggested that the sterically bulky TBDPS protecting groups so close to the ester moiety restricts access of these substrates into the hydrophobic active site of CAL-B. Transesterification failed altogether with the 6'-deacetoxy peracylated derivatives, 5 and $\mathbf{6}$, once again suggesting that the hydrophobic pocket of the enzyme, which optimally fits the acyl moiety of the substrates, experiences steric conflicts due to unfavorable van der Waals interactions.

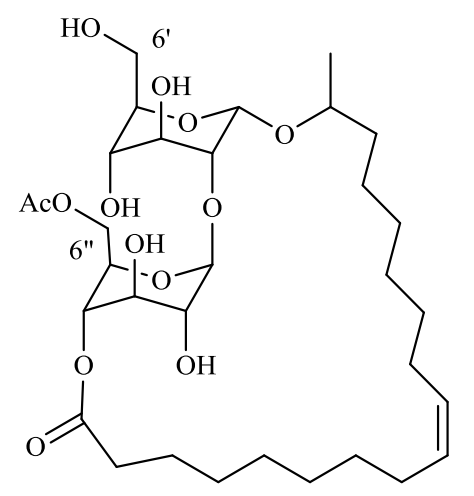

(4)

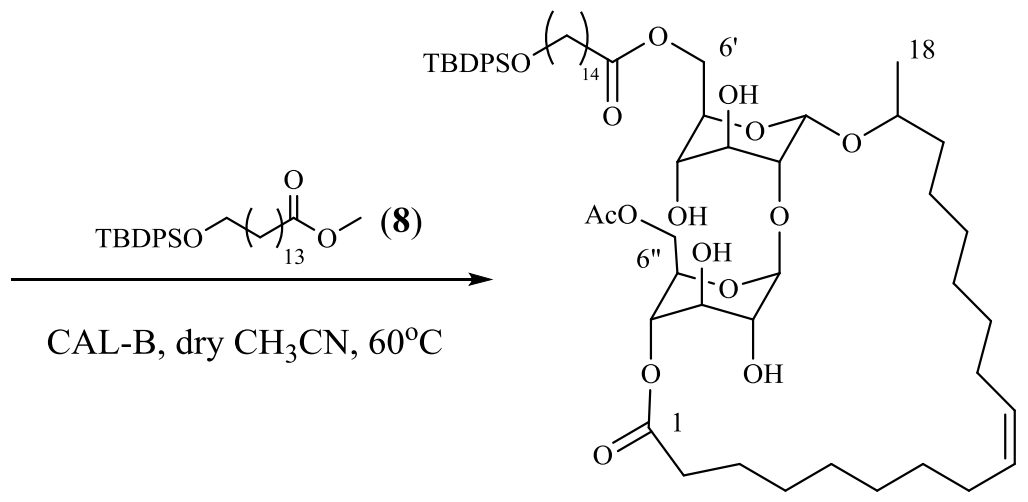

(13)

Scheme 4. CAL-B catalyzed transesterification of 6'deacetylated macrolactonic sophorolipid (4).

\begin{tabular}{|l|l|l|l|l|}
\hline Compound code & Temperature $\left({ }^{\circ} \mathrm{C}\right)$ & Duration (\# of & Solvent & Isolated yield (\%) \\
\hline
\end{tabular}




\begin{tabular}{|c|c|c|c|c|}
\hline & & days & & \\
\hline $\mathbf{4 + 8}$ & 60 & 5 & neat $^{\mathrm{a}}$ & 12 \\
\hline $\mathbf{4 + 8}$ & 60 & 5 & THF & 11 \\
\hline $\mathbf{4 + 8}$ & 60 & 5 & toluene & 39 \\
\hline $\mathbf{4 + 8}$ & 60 & 5 & $\mathrm{CH}_{3} \mathrm{CN}$ & 30 \\
\hline $\mathbf{4 + 8}$ & 60 & 30 & neat $^{\mathrm{a}}$ & 32 \\
\hline $\mathbf{4 + 8}$ & 60 & 30 & THF & 57 \\
\hline $\mathbf{4 + 8}$ & 60 & 30 & $\mathrm{CH}_{3} \mathrm{CN}$ & 0 \\
\hline $\mathbf{4 + 8}$ & 60 & 30 & $\mathrm{THF}$ & 0 \\
\hline $\mathbf{4 + 1 0}$ & 60 & 7 & $\mathrm{CH}_{3} \mathrm{CN}$ & 0 \\
\hline $\mathbf{4 + 1 2}$ & 60 & 7 & $\mathrm{THF}$ & 0 \\
\hline $\mathbf{5 + 8}$ & 60 & 7 & $\mathrm{CH}_{3} \mathrm{CN}$ & \\
\hline $\mathbf{6 + 8}$ & 60 & & & 0 \\
\hline
\end{tabular}

${ }^{\mathrm{a}}$ (in the absence of solvent)

Table 2. Solvent effects on yield of CAL-B catalyzed transesterification reactions of 6'deacetylated SLMLs with fatty acid esters.

\subsection{Structure determinations}

Compound 1a was incubated with CAL-B at $60^{\circ} \mathrm{C}$ for $72 \mathrm{~h}$ with excess $n$-butanol in dry acetonitrile successfully affording the monoacetate 4 (Scheme 1) selectively hydrolyzing the C$6^{\prime}$ acetate, in $50 \%$ yield. The disappearance of a $\mathrm{CH}_{3}$ - group in the ${ }^{1} \mathrm{H} \mathrm{NMR}$ spectrum of 4 with the simultaneous upfield shift of two protons for $6^{\prime}-\mathrm{CH}_{2^{-}}$from $4.29 \mathrm{ppm}$ to $3.80 \mathrm{ppm}$ corresponds to the formation of the 6' hydroxymethylene group. The resonances for the $6^{\prime \prime}-\mathrm{CH}_{2}-$ and the 6" acetoxy group remained unperturbed reflecting the selective hydrolysis of the 6'acetoxy group. The ${ }^{13} \mathrm{C}$ NMR spectrum of compound 4 along with its ${ }^{13} \mathrm{C}$ DEPT 135 spectra (Figure 2a,b), when compared to 1a, show an upfield shift of $\sim 2.4 \mathrm{ppm}$ for the C-6', a downfield shift of $\sim 1.2 \mathrm{ppm}$ for $\mathrm{C}-5^{\prime}$, and an upfield shift of $\sim 0.1 \mathrm{ppm}$ for $\mathrm{C}-4^{\prime}$. The effects of such alternating resonances are known when sugars are deacylated at the hydroxymethylene positions, the $\gamma$-effect. The resonances of the C-6", C-5", and C-4" remained relatively unperturbed between 1a and 4. Proton resonances were established using additional 2D techniques. The other derivatized macrolactonic products $\left(\mathbf{5}, \mathbf{6}\right.$ and 13) were unambiguously characterized using ${ }^{1} \mathrm{H}-{ }^{1} \mathrm{H}$ 
COSY, HSQC and HMBC spectra. The deacylated products, $\mathbf{5}$ and $\mathbf{6}$, and the esterified product, 13, showed similar alternating resonance patterns upon close examination of their ${ }^{13} \mathrm{C}$ NMR and ${ }^{13} \mathrm{C}$ DEPT 135 spectra. In addition, a mixture of equimolar amounts of $\mathbf{1 a}$ and 4 (Figure 2c) showed distinctly resolved resonances for $1 \mathbf{a}$ at $63.8\left(\mathrm{C}-6^{\prime}\right), 73.8\left(\mathrm{C}-5^{\prime}\right)$ and $69.7\left(\mathrm{C}-4^{\prime}\right)$ and for 4 at $61.3\left(\mathrm{C}-6^{\prime}\right), 75.0\left(\mathrm{C}-5^{\prime}\right)$ and $69.6\left(\mathrm{C}-4^{\prime}\right)$. Such observations led to the conclusion that CAL-B was an effective biocatalyst for the selective hydrolysis of compounds $\mathbf{1 a}, \mathbf{2}$, and $\mathbf{3}$ at the C-6' position or esterification of compound 4 at the C-6' position. Finally, all compounds were carefully confirmed by HRMS analysis and the data obtained show good agreement between experimental and calculated values (see experimental section).
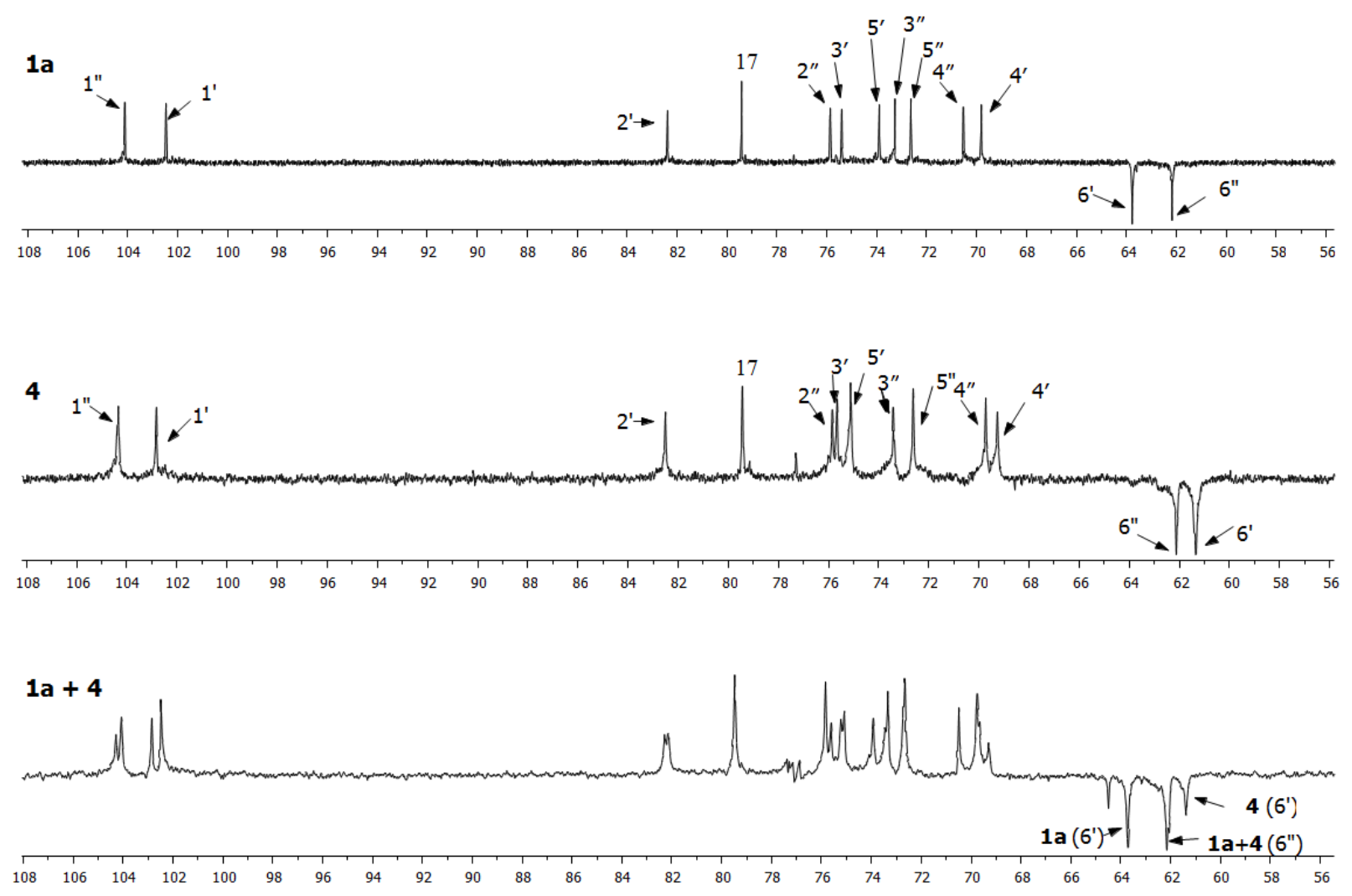

Figure 2. Dept-135 Spectra from 56-108ppm for $\mathbf{1 a}, \mathbf{4}$, and a mixture of $\mathbf{1 a}$ and $\mathbf{4}$ in $\mathrm{CDCl}_{3}$.

\section{Concluding Remarks}

Chemical modifications of sophorolipids, due to their complexity, have always been a challenging undertaking because of the hydrolysable glycosidic linkages, the sensitive ester moieties located at the $6^{\prime}$ and 6" positions (and the macrolactonic ester formed between the 17- 
hydroxy oleic acid and the sophorose ring), or the global presence of numerous hydroxyl groups. This study represents a careful examination of the lipase-catalyzed modification of sophorolipid macrolactone and its esterified derivatives. Derivatization was accomplished without the need for protection/deprotection steps in the preparation of the 6'deacetylated macrolactones. CAL-B (Novozym-435) was found to be the best biocatalyst to accomplish this highly selective process with dry acetonitrile at $60^{\circ} \mathrm{C}$ being the most favorable conditions. To the best of our knowledge, this is the first careful study of the limitations of lipase modification of macrolactonic sophorolipids. The reactions were found to be scalable, thus providing an avenue by which macrolactonic derivatives can be chemo-enzymatically synthesized in our ongoing investigations into their interfacial functions. Since sophorolipids are known active therapeutic agents, biological activities of all new compounds $(2, \mathbf{3}, \mathbf{4}, \mathbf{5}, \mathbf{6}, \mathbf{1 3})$ are under investigation and will be reported separately.

\section{Experimental section}

\subsection{General methods}

The NMR spectra were measured on a JEOL ECA-500 spectrometer at $500 \mathrm{MHz}\left({ }^{1} \mathrm{H}\right), 125$ $\mathrm{MHz}\left({ }^{13} \mathrm{C}\right)$ in $\mathrm{CDCl}_{3}$ at ambient temperature. The ${ }^{1} \mathrm{H}$ and ${ }^{13} \mathrm{C}$ chemical shifts were referenced to the internal standard, TMS, and values recorded on the ppm scale $(\delta) . J$ values are given in $\mathrm{Hz}$. HRMS were recorded on a LCT Premier TOF mass spectrometer from Waters. IR spectra were recorded on a Nicolet IS5 FTIR spectrometer over a range of 400-4000 $\mathrm{cm}^{-1}$. TLC was carried out on Sigma Aldrich Fluka TLC plate with silica gel matrix. For column chromatography, Fisher Scientific, 0.035-0.070 mm, 60A silica gel was used for flash chromatography. Candida antartica lipase (CAL-B) was purchased from Sigma-Aldrich and all other lipases were donated from Amano Enzyme, USA. The sophorolipid macrolactone was donated by the United States Department of Agriculture (USDA). For all reactions, HPLC solvents were used where applicable or solvents were purified per established procedures.

\subsection{Procedure for the preparation of peracylated SLMLS}




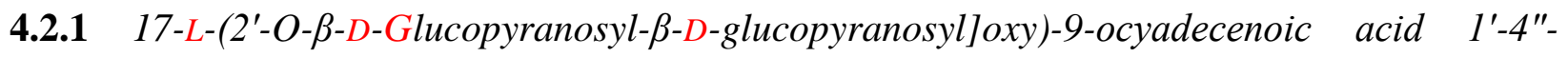
lactone $3^{\prime}, 4^{\prime}, 6^{\prime}, 2^{\prime \prime}, 3^{\prime \prime}, 6^{\prime \prime}-$ hexaacetate (2)

To a solution of $1.0 \mathrm{~g}$ of $\mathbf{1 a}(1.45 \mathrm{mmol})$ in dry THF $(15 \mathrm{~mL})$ was added acetic anhydride $(0.67 \mathrm{~g}, 6.54 \mathrm{mmol})$ and pyridine $(0.52 \mathrm{~g}, 6.54 \mathrm{mmol})$ along with a catalytic amount of DMAP $(100 \mathrm{mg})$. The mixture was allowed to stir at ambient temperature for a period of $2 \mathrm{~h}$. The reaction mixture was then concentrated under reduced pressure, and the crude material was taken up in ethyl acetate $(25 \mathrm{~mL})$ and washed first with a concentrated solution of sodium bicarbonate $(25 \mathrm{~mL})$ then brine $(25 \mathrm{~mL})$. The organic layer was dried over anhydrous sodium sulfate and then concentrated to dryness which upon standing yielded a white waxy solid. Yield: $1.23 \mathrm{~g}$, 99\%. TLC: $\mathrm{R}_{f}=0.62$ (1:1 ethyl acetate: hexane); $\mathrm{mp}=75-77{ }^{\circ} \mathrm{C}$; IR $\left(\mathrm{cm}^{-1}\right): 2921,1746,1221$, 1034; NMR: ${ }^{1} \mathrm{H}$ NMR (500 MHz, $\mathrm{CDCl}_{3}, \delta$ ): 1.23 (d, $\left.J=5 \mathrm{~Hz}, 3 \mathrm{H}, \mathrm{H}-18\right), 1.26-1.59$ (m, 24H, H3-8 and 11-16), 1.97 (s, 3H, (CO)CH $\left.\mathrm{CH}_{3}\right), 1.99$ (s, 3H, (CO)CH $\left.\mathrm{CH}_{3}\right), 2.04$ (s, 3H, $\left.(\mathrm{CO}) \mathrm{CH}_{3}\right), 2.04$ (s, $\left.3 \mathrm{H},(\mathrm{CO}) \mathrm{CH}_{3}\right), 2.05\left(\mathrm{~s}, 3 \mathrm{H},(\mathrm{CO}) \mathrm{CH}_{3}\right), 2.08\left(\mathrm{~s}, 3 \mathrm{H},(\mathrm{CO}) \mathrm{CH}_{3}\right), 2.19-2.32(\mathrm{~m}, 2 \mathrm{H}, \mathrm{H}-2), 3.62-$ 3.67 (m, 2H, H-5', 5"), 3.70-3.76 (m, 2H, H-2', 17), 4.05-4.16 (m, 4H, H-6', 6"), 4.47 (d, J= 8 Hz, 1H, H-1'), 4.84-4.93 (m, 4H, H-1", 2", 3", 4'), 5.09-5.19 (m, 2H, H-3', 4"), 5.28-5.36 (m, 2H, H-9,10); ${ }^{13} \mathrm{C}$ NMR (125 MHz, $\left.\mathrm{CDCl}_{3}, \delta\right): 20.57,20.60,20.69,20.78,21.07,23.99,25.15,26.64$, 27.30, 27.38, 27.71, 28.48, 30.28, 30.40, 33.49, 37.17, 62.00, 62.30, 67.77, 68.84, 71.40, 72.00, 72.52, 72.77, 74.04, 79.17, 99.63, 102.25, 129.58, 130.24, 169.36, 169.70, 169.96, 170.22, 170.49, 170.59, 171.96; HRMS (TOF-ES+) m/z Calcd. For $\left(\mathrm{C}_{42} \mathrm{H}_{64} \mathrm{O}_{18}+\mathrm{Na}\right)^{+}$879.3990, found: 879.3990 .

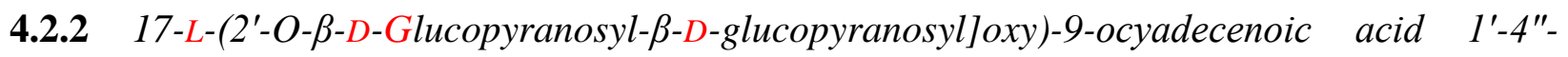
lactone 6', 6"-diacetyl-3', 4',2", 3"-tetrapropionate (3)

To a solution of $1.0 \mathrm{~g}$ of $\mathbf{1 a}(1.45 \mathrm{mmol})$ in dry THF $(15 \mathrm{~mL})$ were added propionic anhydride $(0.83 \mathrm{~mL}, 6.54 \mathrm{mmol})$ and pyridine $(0.52 \mathrm{~mL}, 6.54 \mathrm{mmol})$ along with a catalytic amount of DMAP $(100 \mathrm{mg})$. The mixture was allowed to stir at ambient temperature for a period of $2 \mathrm{~h}$ after which the reaction mixture was concentrated under reduced pressure, and the crude material taken up in ethyl acetate $(25 \mathrm{~mL})$. The solution was washed with a concentrated solution of sodium bicarbonate $(25 \mathrm{~mL})$ then brine $(25 \mathrm{~mL})$. The organic layer was then dried over anhydrous sodium sulfate and then concentrated to dryness which upon standing yielded a white 
waxy solid. Yield: $1.30 \mathrm{~g}, 99 \%$. TLC: $\mathrm{R}_{f}=0.65\left(1: 1\right.$ ethyl acetate: hexane); $\mathrm{mp}=78^{\circ} \mathrm{C}$; $\mathrm{IR}\left(\mathrm{cm}^{-}\right.$ $\left.{ }^{1}\right)$ : 2930, 1744, 1161, 1027; NMR: ${ }^{1} \mathrm{H}$ NMR $\left(500 \mathrm{MHz}, \mathrm{CDCl}_{3}, \delta\right): 0.98-1.07$ (m, 12H, 4x $\left.(\mathrm{CO}) \mathrm{CH}_{2} \mathrm{CH}_{3}\right), 1.18$ (d, $\left.J=6 \mathrm{~Hz}, 3 \mathrm{H}, \mathrm{H}-18\right), 1.21-1.52$ (m, 24H, H-3-8 and 11-16), 2.00 (s, 3H, $\left.(\mathrm{CO}) \mathrm{CH}_{3}\right), 2.04\left(\mathrm{~s}, 3 \mathrm{H},(\mathrm{CO}) \mathrm{CH}_{3}\right), 2.15-2.33\left(\mathrm{~m}, 10 \mathrm{H}, 4 \mathrm{x}(\mathrm{CO}) \mathrm{CH}_{2} \mathrm{CH}_{3}, \mathrm{H}-2\right), 3.56-3.63(\mathrm{~m}, 2 \mathrm{H}$, H-5", 5'), 3.67-3.70 (m, 2H, H-2', 17), 3.99-4.18 (m, 4H, H-6', 6"), 4.43 (d, $J=8 \mathrm{~Hz}, 1 \mathrm{H}, \mathrm{H}-1^{\prime}$ ), 4.79 (d, $\left.J=8 \mathrm{~Hz}, 1 \mathrm{H}, \mathrm{H}-1^{\prime \prime}\right), 4.84-4.89$ (m, 2H, H-2", 4'), 5.05-5.16 (m, 3H, H-3", 3', 4"), 5.245.32 (m, 2H, H-9,10); ${ }^{13} \mathrm{C}$ NMR (125 MHz, $\left.\mathrm{CDCl}_{3}, \delta\right): 8.78,8.80,8.88,20.57,20.67,20.99$, $23.82,25.06,26.54,27.05,27.21,27.28,27.47,27.57,28.31,30.25,30.26,30.36,33.28,37.09$, $61.96,62.22,67.70,68.54,71.38,71.89,72.18,72.50,73.84,76.61,79.08,99.51,102.16$, 129.42, 130.17, 170.38, 170.44, 171.81, 172.77, 173.02, 173.27, 173.48; HRMS (TOF-ES+) $\mathrm{m} / \mathrm{z}$ Calcd. For $\left(\mathrm{C}_{46} \mathrm{H}_{72} \mathrm{O}_{18}+\mathrm{Na}\right)^{+} 935.4616$, found: 935.4643 .

\subsection{Procedure for lipase catalyzed hydrolysis of macrolactonic sophorolipids}

4.3.1 17-L-(2'-O- $\beta$-D-Glucopyranosyl- $\beta$-D-glucopyranosyl]oxy)-9-ocyadecenoic acid $\quad l^{\prime}-4$ "lactone 6"-acetate (4)

A solution of the sophorolipid macrolactone $(1 \mathbf{a})(0.500 \mathrm{~g}, 0.73 \mathrm{mmol})$ in dry THF or acetonitrile $(4 \mathrm{~mL})$ was incubated with Novozym-435 $(0.250 \mathrm{~g})$ and $n$-butanol $(0.14 \mathrm{~mL}, 1.5$ $\mathrm{mmol}$ ) in an $\mathrm{N}_{2}$-flushed $10 \mathrm{ml}$ vial at $60^{\circ} \mathrm{C}$ for $72 \mathrm{~h}$. The enzyme was filtered over a bed of celite, followed by washing with THF $(2 \times 3 \mathrm{~mL})$. The filtrate was concentrated in vacuo and the residue was subjected to purification via column chromatography using a gradient eluent of ethyl acetate: petroleum ether (1:1) then ethyl acetate to afford the $6^{\prime}$-deacetylated product as a white solid (4) $(0.236 \mathrm{~g}$, yield $=50 \%)$. TLC: $\mathrm{R}_{f}=0.1(100 \%$ ethyl acetate $) ; \mathrm{mp}=109-111^{\circ} \mathrm{C} ; \mathrm{IR}\left(\mathrm{cm}^{-1}\right)$ : 3364, 2927, 1744, 1072; ${ }^{1} \mathrm{H}$ NMR (500 MHz, $\mathrm{CDCl}_{3}, \delta$ ): 1.24 (d, $\left.J=6 \mathrm{~Hz}, 3 \mathrm{H}, \mathrm{H}-18\right), 1.30$ (m, 15H, H-4-7 and 12-14,15), 1.44-1.52 (m, 2H, H-15, 16), 1.55-1.66 (m, 3H, H-3, 16), 1.98-2.04 (m, 4H, H-8,11), 2.07 (s, 3H, (CO) $\mathrm{CH}_{3}$ ), 3.32-2.38 (m, 3H, H-2, H-5'), 3.43-3.56 (m, 1H, H-3'), 3.64-3.67 (m, 4H, H-2', 4', 2", 5"'), 3.75-3.87 (m, 4H, H-17, 3", 6'), 4.09-4.18 (m, 2H, H-6"), 4.49 (d, $\left.J=6.5 \mathrm{~Hz}, 1 \mathrm{H}, \mathrm{H}-1^{\prime}\right), 4.56$ (d, $\left.J=7 \mathrm{~Hz}, 1 \mathrm{H}, \mathrm{H}-1^{\prime \prime}\right), 4.96-5.00$ (t, $1 \mathrm{H}, J=9.5 \mathrm{~Hz}, \mathrm{H}-4^{\prime \prime}$ ), 5.30-5.39 (m, 2H, H-9, 10); ${ }^{13} \mathrm{C}$ NMR (125 MHz, $\mathrm{CDCl}_{3}, \delta$ ): 20.79, 21.08, 24.77, 25.53, 26.92, $27.11,28.24,28.30,28.39,29.03,29.65,30.15,34.31,37.59,61.25,62.02,69.18,69.61,72.51$, 
73.31, 75.01, 75.54, 75.75, 79.32, 82.39, 102.72, 104.24, 129.78, 129.90, 170.46, 173.11; HRMS (TOF-ES+) $\mathrm{m} / z$ Calcd. for $\left(\mathrm{C}_{32} \mathrm{H}_{54} \mathrm{O}_{13}+\mathrm{Na}\right)^{+}$669.3462, found: 669.3483 .

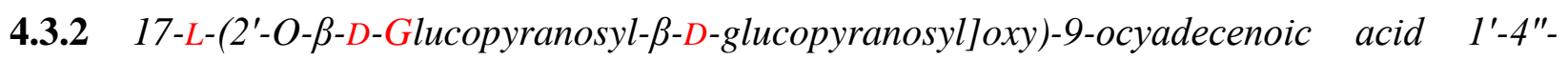
lactone $3^{\prime}, 4^{\prime}, 2^{\prime \prime}, 3^{\prime \prime}, 6^{\prime \prime}$ - pentaacetate (5)

A solution of the $3^{\prime}, 4^{\prime}, 6^{\prime}, 2^{\prime \prime}, 3^{\prime \prime}, 6^{\prime \prime}$-sophorolipid macrolactone hexaacetate (2) (0.500 g, 0.58 $\mathrm{mmol})$ in dry acetonitrile $(4 \mathrm{~mL})$ was incubated with Novozym-435 $(0.250 \mathrm{~g})$ and $n$-butanol $(0.35 \mathrm{~mL}, 3.8 \mathrm{mmol})$ in an $\mathrm{N}_{2}$-flushed $10 \mathrm{ml}$ vial at $60^{\circ} \mathrm{C}$ for $72 \mathrm{~h}$. The enzyme was filtered over a bed of celite, followed by washing with acetonitrile $(2 \times 3 \mathrm{~mL})$. The filtrate was concentrated in vacuo and the residue was subjected to purification via column chromatography using ethyl acetate: petroleum ether $(1: 1)$ as the eluent to afford the $6^{\prime}$-deacetylated pentaacetate as a white solid (5) $(0.246 \mathrm{~g}$, yield $=52 \%)$. TLC: $\mathrm{R}_{f}=0.39(50 \%$ ethyl acetate $/ 50 \%$ petroleum ether $) ; \mathrm{mp}=$ 83-85 ${ }^{\circ}$; IR $\left(\mathrm{cm}^{-1}\right): 3524,2925,1746,1221,1035 ;{ }^{1} \mathrm{H}$ NMR $\left(500 \mathrm{MHz}, \mathrm{CDCl}_{3}, \delta\right): 1.23-1.36$ (m, 25H, H-4-8 and 11-16, 18), 1.53-1.62 (m, 2H, H-3), 1.99 (s, 3H, $\left.(\mathrm{CO}) \mathrm{CH}_{3}\right), 2.05$ (s, 3H, $\left.(\mathrm{CO}) \mathrm{CH}_{3}\right), 2.06\left(\mathrm{~s}, 3 \mathrm{H},(\mathrm{CO}) \mathrm{CH}_{3}\right), 2.08\left(\mathrm{~s}, 3 \mathrm{H},(\mathrm{CO}) \mathrm{CH}_{3}\right), 2.09\left(\mathrm{~s}, 3 \mathrm{H},(\mathrm{CO}) \mathrm{CH}_{3}\right), 2.21-2.29(\mathrm{~m}$, 2H, H-2), 3.44-3.47 (m, 1H, H-2'), 3.51-3.55 (m, 1H, H-5'), 3.65-3.78 (m, 3H, H-17, 3', 5"), 4.06-4.20 (m, 4H, H-6", 6'), 4.48 (d, J= 8 Hz, 1H, H-1'), 4.82-4.89 (m, 1H, H-4'), 4.97-5.02 (m, 2H, H-1", 3"), 5.16-5.23 (m, 2H, H-2",4"), 5.29-5.41 (m, 2H, H-9, 10); ${ }^{13} \mathrm{C}$ NMR (125 MHz, $\mathrm{CDCl}_{3}, \delta$ ): 20.57, 20.73, 20.83, 20.91, 24.44, 25.40, 26.57, 27.215, 27.78, 27.83, 28.20, 28.77, $29.34,29.67,29.72,30.06,30.17,31.90,33.97,37.43,61.52,62.63,67.46,70.14,71.53,72.19$, $72.44,73.50,78.86,81.97,100.45,102.14,129.73,129.98,170.12,170.17,170.40,170.65$, 170.74, 171.93; HRMS (TOF-ES+) $\mathrm{m} / z$ Calcd. for $\left(\mathrm{C}_{40} \mathrm{H}_{62} \mathrm{O}_{17}+\mathrm{Na}\right)^{+}$837.3885, found: 837.3874.

4.3.3 17-L-(2'-O- $\beta$-D-Glucopyranosyl- $\beta$-D-glucopyranosyl]oxy)-9-ocyadecenoic acid $\quad l^{\prime}-4 "$ lactone-6"-acetyl-3', 4',2",3"-tetrapropionate (6)

A solution of the $6^{\prime}, 6^{\prime \prime}$-diacetyl-3',4',2",3"'-sophorolipid macrolactone tetrapropionate (3) $(0.500 \mathrm{~g}, 0.55 \mathrm{mmol})$ in dry acetonitrile $(4 \mathrm{ml})$ was incubated with Novozym-435 $(0.250 \mathrm{~g})$ and $n$-butanol $(0.33 \mathrm{ml}, 3.56 \mathrm{mmol})$ in an $\mathrm{N}_{2}$-flushed $10 \mathrm{ml}$ vial at $60^{\circ} \mathrm{C}$ for $72 \mathrm{~h}$. The enzyme was filtered over a bed of celite, followed by washing with acetonitrile $(2 \times 3 \mathrm{~mL})$. The filtrate was 
concentrated in vacuo and the residue was subjected to purification via column chromatography using ethyl acetate: petroleum ether $(1: 1)$ as the eluent to afford the 6'-deacetylated 6"-acetyl$3^{\prime}, 4^{\prime}, 2^{\prime \prime}, 3^{\prime \prime}$-tetrapropionate as a light yellow solid (6) $(0.244 \mathrm{~g}$, yield $=51 \%)$. TLC: $\mathrm{R}_{f}=0.34$ $\left(50 \%\right.$ ethyl acetate $50 \%$ petroleum ether); $\mathrm{mp}=92-95^{\circ} \mathrm{C} ; \mathrm{IR}\left(\mathrm{cm}^{-1}\right): 3510,2939,1744,1161$, 1029; ${ }^{1} \mathrm{H}$ NMR (500 MHz, $\left.\mathrm{CDCl}_{3}, \delta\right):$ 0.97-1.13 (m, 12H, 4x (CO) $\left.\mathrm{CH}_{2} \mathrm{CH}_{3}\right), 1.13-1.46$ (m, 27H, H-3-8 and 11-16, 18), 1.99 (s, 3H, 6"-(CO)CH $), 2.10-2.25$ (m, 10H, 4x (CO) $\left.\mathrm{CH}_{2} \mathrm{CH}_{3}, \mathrm{H}-2\right)$, 3.52-3.59 (m, 3H, H-6'a, 2",3"), 3.60-3.65 (m, 4H, 2', 6'b, 5", 17), 3.92-4.13 (m, 2H, H-6"), 4.52 (d, $\left.J=7.5 \mathrm{~Hz}, 1 \mathrm{H}, \mathrm{H}-1^{\prime}\right), 4.83-4.95$ (m, 3H, H-1", 4", 4'), 5.11-5.16 (m, 1H, H-5'), 5.22-5.28 (m, $1 \mathrm{H}, \mathrm{H}-3$ '), $5.31-5.39$ (m, 2H, H-9, 10); ${ }^{13} \mathrm{C} \mathrm{NMR} \mathrm{(125} \mathrm{MHz,} \mathrm{CDCl}_{3}, \delta$ ): 8.65, 8.74, 20.41, 20.51, 20.87, 23.65, 24.91, 26.41, 26.89, 26.95, 27.05, 27.08, 27.14, 27.30, 27.44, 28.16, 30.13, 30.17, 30.24, 33.11, 36.95, 61.82, 62.04, 67.59, 68.40, 71.25, 71.74, 72.04, 72.36, 73.77, 76.45, 78.90, 99.40, 102.00, 129.25, 130.04, 170.19, 171.65, 172.60, 172.84, 173.09, 173.29; HRMS (ESI) $\mathrm{m} / z$ Calcd. for $\left(\mathrm{C}_{44} \mathrm{H}_{70} \mathrm{O}_{17}+\mathrm{Na}\right)^{+}$893.4510, found: 893.4498.

\subsection{Procedure for the formation of TBDPS-protected hydroxy esters}

\subsubsection{Methyl 15-((tert-butyldiphenylsilyl)oxy)pentadecanoate (8)}

Cyclopentadecanolide $(2.0 \mathrm{~g}, 8.3 \mathrm{mmol})$ and para-toluene sulfonic acid (100 $\mathrm{mg})$ were dissolved in methanol $(25 \mathrm{~mL})$ and the mixture brought to reflux overnight. Excess solvent was removed under reduced pressure and the resulting product was taken up with DCM (40 mL) and washed with deionized water $(10 \mathrm{~mL})$. The organic layer was collected, dried over anhydrous $\mathrm{Na}_{2} \mathrm{SO}_{4}$ and concentrated to dryness to yield methyl 15-hydroxypentadecanoate (7) as a white, waxy solid (1.4 g, 63\% yield). Then, TBDPSCl $(1.5 \mathrm{~mL}, 5.2 \mathrm{mmol})$ was added dropwise to a solution of 7 (1.4 g, $5.2 \mathrm{mmol})$ and imidazole $(0.4 \mathrm{~g}, 5.7 \mathrm{mmol})$ dissolved in DCM (30 mL) and the resulting solution was allowed additional stirring for 2 days at ambient temperature. Excess solvent was then removed under reduced pressure and the crude product was quenched with saturated $\mathrm{NaCl}$ solution $(30 \mathrm{~mL})$ and extracted with diethyl ether $(30 \mathrm{~mL})$. The organic layer was dried over anhydrous $\mathrm{Na}_{2} \mathrm{SO}_{4}$ and concentrated under reduced pressure. Purification of the crude product was done via column chromatography (5\% ethyl acetate/95\% petroleum ether) to afford methyl 15-((tert-butyldiphenylsilyl)oxy)pentadecanoate (8) as a colorless oil (1.5 g, 55\% yield). ${ }^{18}$ TLC: $\mathrm{R}_{f}=0.47$ (5\% ethyl acetate/95\% petroleum ether); IR $\left(\mathrm{cm}^{-1}\right): 3071,2924,1740$, 1110, 823, 700; ${ }^{1} \mathrm{H}$ NMR (500 MHz, $\left.\mathrm{CDCl}_{3}, \delta\right): 1.06$ (s, 9H, $\left.\left(\mathrm{CH}_{3}\right)_{3} \mathrm{CSi}\right), 1.26-1.31$ (m, 20H, 
$\left.10 \mathrm{xCH}_{2}\right), \quad 1.56-1.66\left(\mathrm{~m}, 4 \mathrm{H}, 2 \mathrm{xCH}_{2}\right), 2.30-2.34\left(\mathrm{~m}, 2 \mathrm{H}, \mathrm{CH}_{2} \mathrm{C}=\mathrm{O}\right), 3.67-3.69(\mathrm{~m}, 5 \mathrm{H}$, $\left.\mathrm{OCH}_{3}, \mathrm{CH}_{2} \mathrm{OTBDPS}\right), 7.38-7.44\left(\mathrm{~m}, 6 \mathrm{H}, 6 \mathrm{xCH} \mathrm{Ar}_{\mathrm{Ar}}\right), 7.69-7.71\left(\mathrm{~m}, 4 \mathrm{H}, 4 \mathrm{xCH} \mathrm{Ar}_{\mathrm{Ar}}\right) ;{ }^{13} \mathrm{C} \mathrm{NMR}(125$ $\left.\mathrm{MHz}, \mathrm{CDCl}_{3}, \delta\right): 19.20,24.95,25.75,26.84,29.15,29.26,29.38,29.45,29.61,29.64,3.56$, $34.10,51.44,63.98,127.54,129.45,134.13,135.55,174.34$.

\subsubsection{Ethyl 4-((tert-butyldiphenylsilyl)oxy)octanoate (10)}

$\gamma$-Octanoic lactone $(1.0 \mathrm{~g}, 7 \mathrm{mmol})$ was added to a solution of $\mathrm{NaOH}(0.3 \mathrm{~g}, 7 \mathrm{mmol})$ dissolved in ethanol (90\%) and the mixture was stirred at 80 degrees for 30 min then at ambient temperature for $2 \mathrm{~h}$. Excess solvent was then removed under reduced pressure to yield the sodium salt quantitatively. Thereafter, ethyl iodide $(1.1 \mathrm{~mL}, 14 \mathrm{mmol})$ was added dropwise to a solution of the sodium salt $(1.2 \mathrm{~g}, 7 \mathrm{mmol})$ in DMF $(20 \mathrm{~mL})$ and the solution was allowed to stir at room temperature for an additional 5 days. The solution was taken up in ethyl acetate and washed with water and the organic layer was dried over anhydrous $\mathrm{Na}_{2} \mathrm{SO}_{4}$ and concentrated in vacuo to afford the ethyl ester, 9, as a yellow liquid. The crude ester, 9, and imidazole $(0.5 \mathrm{~g}, 7.7$ mmol) were dissolved in dry DCM (30 mL) and TBDPSCl $(1.8 \mathrm{~mL}, 7 \mathrm{mmol})$ was added dropwise to the solution at room temperature. This mixture was allowed to stir for an additional 2 days after which the solvent was removed under reduced pressure and the crude product was quenched with saturated $\mathrm{NaCl}$ solution $(30 \mathrm{~mL})$ followed by extraction with diethyl ether $(2 \times 20$ $\mathrm{mL}$ ). The organic layers were dried over anhydrous $\mathrm{Na}_{2} \mathrm{SO}_{4}$, concentrated to dryness and the crude product purified via column chromatography (5\% ethyl acetate/95\% petroleum ether) to give the desired product $(\mathbf{1 0})$ as a colorless oil $(1.94 \mathrm{~g}$, yield $=65 \%) .{ }^{19} \mathrm{TLC}: \mathrm{R}_{f}=0.65$ (5\% ethyl acetate/95\% petroleum ether); IR $\left(\mathrm{cm}^{-1}\right)$ : 3071, 2931, 1734, 1105, 821, 700; ${ }^{1} \mathrm{H}$ NMR (500 $\left.\mathrm{MHz}, \mathrm{CDCl}_{3}, \delta\right): 0.74-0.77\left(\mathrm{t}, 3 \mathrm{H}, J=7.5 \mathrm{~Hz}, 6.5 \mathrm{~Hz}, \mathrm{CH}_{3}\right), 1.06-1.13\left(\mathrm{~m}, 11 \mathrm{H}, \mathrm{CH}_{2}\right.$, $\left.\left(\mathrm{CH}_{3}\right)_{3} \mathrm{CSi}\right), 1.21-1.24\left(\mathrm{t}, 3 \mathrm{H}, J=7.5 \mathrm{~Hz}, 7 \mathrm{~Hz}, \mathrm{CH}_{3} \mathrm{CH}_{2} \mathrm{O}\right), 1.37-1.41$ (m, 2H, $\mathrm{CH}_{2}$ ), 1.73-1.85 $\left(\mathrm{m}, 2 \mathrm{H}, \mathrm{CH}_{2}\right), 2.34-2.37\left(\mathrm{~m}, 2 \mathrm{H}, \mathrm{CH}_{2} \mathrm{C}(\mathrm{O})\right), 3.75-3.78(\mathrm{~m}, 1 \mathrm{H}, \mathrm{SiOCH}), 4.03-4.10(\mathrm{~m}, 2 \mathrm{H}$, $\left.\mathrm{OCH}_{2}\right), 7.36-7.44\left(\mathrm{~m}, 6 \mathrm{H}, 4 \mathrm{xCH} H_{\mathrm{Ar}}\right), 7.66-7.69\left(\mathrm{~m}, 4 \mathrm{H}, 4 \mathrm{xCH} \mathrm{Hr}_{\mathrm{Ar}}\right) ;{ }^{13} \mathrm{C} \mathrm{NMR}\left(125 \mathrm{MHz}, \mathrm{CDCl}_{3}\right.$, ठ): $13.93,14.18,19.37,22.53,27.03,29.74,30.97,35.85,60.17,72.21,127.38,127.47,129.44$, $129.50,134.16,134.48,135.86,173.91$.

\subsubsection{Ethyl 5-((tert-butyldiphenylsilyl)oxy)pentanoate (12)}


Valerolactone $(1.0 \mathrm{~g}, 10 \mathrm{mmol})$ was added to a solution of $\mathrm{NaOH}(0.44 \mathrm{~g}, 11 \mathrm{mmol})$ dissolved in ethanol $(90 \%, 23 \mathrm{~mL})$ and the mixture was stirred at 80 degrees for 30min then at ambient temperature for $2 \mathrm{~h}$. Excess solvent was then removed under reduced pressure to yield the sodium salt quantitatively. Thereafter, ethyl iodide $(1.4 \mathrm{~mL}, 17.2 \mathrm{mmol})$ was added dropwise to a solution of the sodium salt $(1.2 \mathrm{~g}, 8.6 \mathrm{mmol})$ in DMF $(20 \mathrm{~mL})$ and the solution was allowed to stir at room temperature for an additional 5 days. The solution was then taken up in ethyl acetate $(30 \mathrm{~mL})$ and washed with water. The organic layer was dried over anhydrous $\mathrm{Na}_{2} \mathrm{SO}_{4}$ and then concentrated to dryness to afford the crude ethyl ester, 11, as a yellow liquid. The crude ester, 11, and imidazole $(0.6 \mathrm{~g}, 9.5 \mathrm{mmol})$ were dissolved in dry DCM $(30 \mathrm{~mL})$ and TBDPSCl $(2.2 \mathrm{~mL}$, $8.6 \mathrm{mmol}$ ) was added dropwise to the solution at room temperature. This mixture was allowed to stir for an additional 2 days after which the solvent was removed under reduced pressure and quenched with saturated $\mathrm{NaCl}$ solution $(30 \mathrm{~mL})$ followed by extraction with diethyl ether $(2 \times 20$ $\mathrm{mL}$ ). The organic layers were dried over anhydrous $\mathrm{Na}_{2} \mathrm{SO}_{4}$, the solvent removed in vacuo and the crude product was purified via column chromatography (5\% ethyl acetate/95\% petroleum ether) to give the desired product $(\mathbf{1 2})$ as a colorless oil $(2.1 \mathrm{~g}$, yield $=63 \%) .{ }^{19}$ TLC: $\mathrm{R}_{f}=0.28$ (5\% ethyl acetate/95\% petroleum ether); IR $\left(\mathrm{cm}^{-1}\right): 3071,2931,1734,1108,822,700 ;{ }^{1} \mathrm{H}$ NMR $\left(500 \mathrm{MHz}, \mathrm{CDCl}_{3}, \delta\right): 1.13\left(\mathrm{~s}, 9 \mathrm{H},\left(\mathrm{CH}_{3}\right)_{3} \mathrm{CSi}\right), 1.27-1.30\left(\mathrm{t}, 3 \mathrm{H}, J=7.5 \mathrm{~Hz}, 7 \mathrm{~Hz}, \mathrm{CH}_{3} \mathrm{CH}_{2} \mathrm{O}\right)$, 1.64-1.69 (m, 2H, $\left.\mathrm{CH}_{2}\right), 1.78-1.82\left(\mathrm{~m}, 2 \mathrm{H}, \mathrm{CH}_{2}\right), 2.33-2.37\left(\mathrm{~m}, 2 \mathrm{H}, \mathrm{CH}_{2}\right), 3.72-3.75(\mathrm{~m}, 2 \mathrm{H}$, $\left.\mathrm{CH}_{2}\right), 4.14-4.19\left(\mathrm{~m}, 2 \mathrm{H}, \mathrm{OCH}_{2} \mathrm{CH}_{3}\right), 7.40-7.46\left(\mathrm{~m}, 6 \mathrm{H}, 6 \times \mathrm{CH}_{A r}\right), 7.72-7.79\left(\mathrm{~m}, 4 \mathrm{H}, 4 \mathrm{xCH} \mathrm{H}_{\mathrm{Ar}}\right) ;{ }^{13} \mathrm{C}$ NMR (125 MHz, $\left.\mathrm{CDCl}_{3}, \delta\right): 14.15,19.11,21.37,26.76,31.82,33.92,60.06,63.28,127.54$, $129.48,133.79,133.79,134.73,135.46,173.53$.

\subsection{Procedure for $C A L-B$ catalyzed transesterification reaction}

4.5.1 6'-(15-((tert-Butyldiphenylsilyl)oxy)pentadecanoyl)-17-L-(2'-O- $\beta$-D-glucopyranosyl- $\beta$-Dglucopyranosyl]oxy)-9-ocyadecenoic acid 1'-4"-lactone 6"-monoacetate (13)

A solution of the 6'-deacetylated SLML (4) $(0.2 \mathrm{~g})$ in dry acetonitrile $(3 \mathrm{~mL})$ was incubated with Novozym-435 (2:1 w/w, $0.1 \mathrm{~g})$ and methyl 15-((tert-butyldiphenylsilyl)oxy)pentadecanoate (8) $(0.2 \mathrm{~g}, 0.39 \mathrm{mmol})$ in an $\mathrm{N}_{2}$-flushed $10 \mathrm{ml}$ vial at $60^{\circ} \mathrm{C}$ for 30 days. The enzyme was filtered over a bed of celite, followed by washing with acetonitrile $(3 \times 3 \mathrm{~mL})$. The filtrate was concentrated in vacuo and the residue was subjected to purification via column chromatography 
using ethyl acetate as the eluent to give 6'-(15-((tert-butyldiphenylsilyl)oxy)pentadecanoyl)-6"acetyl sophorolipid macrolactone (13) as a yellow waxy solid (209 mg). Yield: 61\%; TLC: $\mathrm{R}_{f}=$ 0.38 (100\% ethyl acetate). IR $\left(\mathrm{cm}^{-1}\right): 3381,2924,2853,1742,1075,701 ;{ }^{1} \mathrm{H}$ NMR (500 MHz, $\left.\mathrm{CDCl}_{3}, \delta\right): 1.04$ (s, 9H, $\left.\left(\mathrm{CH}_{3}\right)_{3} \mathrm{CSi}\right)$ ), 1.24-1.36 (m, 39H, H-18, 18x $\left.\mathrm{CH}_{2}\right), 1.53-1.65$ (m, 10H, $\left.5 \mathrm{xCH}_{2}\right), 2.00-2.04\left(\mathrm{~m}, 2 \mathrm{H}, \mathrm{CH}_{2}\right), 2.08\left(\mathrm{~s}, 3 \mathrm{H}, 6{ }^{\prime \prime}(\mathrm{CO}) \mathrm{CH}_{3}\right), 2.32-2.38(\mathrm{~m}, 4 \mathrm{H}, 2 \mathrm{xCH}$ ), 3.34-3.44 $\left(\mathrm{m}, 2 \mathrm{H}, \mathrm{H}-5^{\prime}, 5^{\prime \prime}\right), 3.52-3.56\left(\mathrm{~m}, 2 \mathrm{H}, \mathrm{H}-2^{\prime}, 2^{\prime \prime}\right), 3.63-3.70\left(\mathrm{~m}, 6 \mathrm{H}, \mathrm{H}-3{ }^{\prime \prime}, 3^{\prime}, 4^{\prime}, 4^{\prime \prime}\right.$, $\mathrm{CH}_{2} \mathrm{OTBDPS}$ ), 3.75-3.78 (m, 1H, H-17), 4.13-4.21 (m, 2H, H-6"), 4.26-4.32 (m, 1H, H-6'a), 4.39-4.43 (m, 1H, H-6'b), 4.47 (d, J=7.5 Hz, 1H, H-1'), 4.56 (d, J = 7.5 Hz, 1H, H- 1"), 5.31-

$5.39(\mathrm{~m}, 2 \mathrm{H}, \mathrm{H}-9,10), 7.35-7.42\left(\mathrm{~m}, 6 \mathrm{H}, 6 \mathrm{xCH} H_{A r}\right), 7.65-7.67\left(\mathrm{~m}, 4 \mathrm{H}, 4 \times \mathrm{xCH}_{A r}\right) ;{ }^{13} \mathrm{C} \mathrm{NMR}(125$ $\left.\mathrm{MHz}, \mathrm{CDCl}_{3}, \delta\right): 19.22,20.78,21.33,24.72,24.90,25.05,25.78,26.87,27.03,27.22,28.14$, 28.34, 29.06, 29.15, 29.29, 29.39, 29.49, 29.63, 29.68, 29.77, 29.88, 32.59, 34.18, 34.31, 62.04, 63.15, 64.02, 69.75, 70.40, 72.89, 73.48, 74.06, 74.31, 75.43, 79.47, 80.68, 102.32, 103.06, 127.54, 129.45, 129.79, 130.00, 134.21, 135.57, 170.56, 173.27, 174.70; HRMS (TOF-ES+) $\mathrm{m} / z$ Calcd. for $\left(\mathrm{C}_{63} \mathrm{H}_{100} \mathrm{O}_{15} \mathrm{Si}+\mathrm{Na}\right)^{+} 1147.6730$, found: 1147.6735 .

\section{Acknowledgements}

The authors gratefully recognize Sam Lazar of Amano Enzyme, USA for his generous donation of samples of lipases and Dr. Richard Ashby of the USDA for a sample of the macrolactonic sophorolipid.

\section{References}

1. Shah, V.; Badia, D.; Ratsep, P. Antimicrob. Agents Chemother. 2007, 51, 1, 397-400.

2. Fu, S.L.; Wallner, S.R.; Bowne, W.B.; Hagler, M.D.; Zenilman, M.E.; Gross, R.; Bluth, M.H. J. Surg Res 2008, 148, 77-82.

3. Chen, J.; Song, X.; Zhang, H.; Qu, Y.; Miao, J. Appl Microbiol Biotechnol, 2006, 72, 5259.

4. Shah, V.; Doncel, G.F.; Seyoum, T.; Eaton, K.M.; Zalenskaya, I.; Hagver, R.; Azim, A.; Gross, R. Antimicrob. Agents Chemother. 2005, 49, 10, 4093-4100. 
5. Hardin, R.; Pierre, J.; Schulze, R.; Mueller, C.M.; Fu, S.L.; Wallner, S.R.; Stanek, A.; Shah, V.; Gross, R.; Weedon, J.; Nowakowski, M., Zenilman, M.E.; Bluth, M.H. J. Surg Res 2007, 142, 314-319.

6. Ashby, R.D.; Solaiman, D.K.Y.; Foglia, T.A. Biotechnol. Lett. 2006, 28, 253-260.

7. Hommel, R.K.; Weber, L.; Weiss, A.; Himmelireich, U.; Rilke, O.; Kleber, H.P. J. Biotechnol. 1994, 33, 147-155.

8. Cutler, A.J.; Light, R.J. J. Biol. Chem. 1979, 254, 1944-1979.

9. Konishi, M.; Fukuoka, T.; Morita, T.; Imura, T.; Kitamoto, D. Journal of Oleo Science 2008, 57, (6) 359-369.

10. Chen, J.; Song, X.; Zhang, H.; Qu. Y. Enzyme \& Microbial. Technol. 2006, 39, 501-506.

11. Delbeke, E.I.P.; Movsisyan, M.; Van Geem, K.M.; Stevens, C.V. Green Chem., 2016, 18, 76.

12. Carr, J.A.; Bisht, K.S. Tetrahedron, 2003, 59, 7713-7724.

13. Laane, C.; Boeran, S.; Vos, K.; Veeger, C. Biotechnol. Bioeng. 1987, 30, 81-87.

14. Otto, R.T.; Daniel, H.J.; Pekin, G.; Müller-Decker, K.; Fürstenberger, G.; Reuss, M.; Syldatk, C. Appl. Microbiol. Biotechnol. 1999, 52, 4, 495-501.

15. Hu, Y.; Ju, L. Biotechnol. Prog. 2003, 19, 303-311.

16. Peng, Y.; Munoz-Pinto, D.J.; Chen, M.; Decatur, J.; Hahn, M.; Gross, R.A. Biomacromolecules 2014, 15, 4214-4227.

17. Pleiss, J.; Fischer, M.; Schmid, R.D. Chem and Phys of Lipids 1998, 97, 67-80.

18. Gouin, S.G.; Pilgrim, W.; Porter, R.K.; Murphy, P.V. Carbohydrate research 2005, 340 (8), 1547-1552.

19. Ferris, T.J.; Went, M.J. Forensic Science International 2012, 216 (1), 158-162. 


\section{Graphical Abstract}

\section{Lipase-mediated regio-selective}

modifications of macrolactonic sophorolipids

Leave this area blank for abstract info.

Aliya Sembayeva ${ }^{\mathrm{a}}$, Beniam Berhane ${ }^{\mathrm{b}}$ and Jason A. Carr ${ }^{\mathrm{a}}$ *

${ }^{a}$ Nazarbayev University, Dept. of Chemistry, 53 Kabanbay batyr Ave., Astana, Republic of Kazakhstan, 010000

${ }^{b}$ University of California Irvine, Dept. of Chemistry, 1102 Natural Sciences 2, Irvine, California, 92697
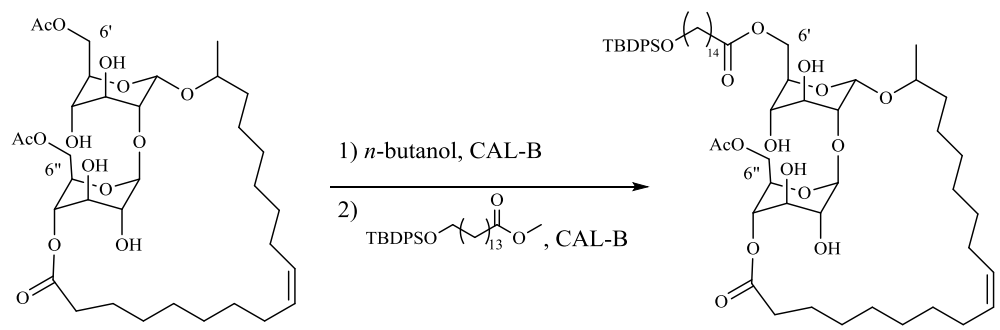